\title{
Siew New Disease Reports \\ First report of Achyrenthes aspera leaf spot disease caused by Curvularia prasadii in India
}

\author{
N. Singh ${ }^{1}$, Pankaj Sharma ${ }^{2,3 *}$ and O.P. Verma ${ }^{4}$ \\ ${ }^{1}$ Present address: Potato Research Station, S.D. Agriculture University, Deesa, Gujarat, India; ${ }^{2}$ Department of Plant \\ Pathology, Maharana Pratap University of Agriculture and Technology, Udaipur 313 001, India; ${ }^{3}$ Present address: \\ Directorate of Rapeseed-Mustard Research (ICAR), Bharatpur 321 303, India; ${ }^{4}$ 61/130, Pratap Nagar Housing Board, \\ Sanganer, Jaipur 302 033, India
}

*E-mail: pksvirus@gmail.com

Received: 01 Mar 2011. Published: 28 Apr 2011. Keywords: fungal plant disease

Achyranthes aspera (Amaranthaceae), commonly known as apamarga in Sanskrit, is a small herb found all over India possessing valuable medicinal properties. It is useful in cough, bronchitis and rheumatism, malarial fever, dysentery, asthma, hypertension and diabetes. Oleanolic acid is one of the constituents of A. aspera that can be isolated from different parts of the plant (Satyavati et al., 1976; Girach \& Khan, 1992). A leaf spot disease of A. aspera was observed during the post-rainy season in a herbal garden at Udaipur, India. Spots were circular, reddish brown with dark margins and a greyish centre, measuring 2-7 $\mathrm{mm}$ in diameter. Adjoining lesions coalesced together resulting in large pustules (Fig.1). Severe infection caused complete defoliation leaving bare twigs. At this stage, further growth of the plant was arrested. Uprooted plants revealed a poorly developed root system compared to healthy plants. Incidence of infection in the surveyed area was almost $100 \%$. However, severity, assessed on leaf infection, varied from $20 \%$ to above $75 \%$.Diseased tissue segments were surface sterilised using $95 \%$ ethanol $(1 \mathrm{~min}), 6 \%$ sodium hypochlorite ( 5 $\mathrm{min})$ and $95 \%$ ethanol $(0.5 \mathrm{~min})$ followed by rinsing in sterile distilled water. The tissue segments were plated on $2 \%$ potato dextrose agar (PDA) supplemented with tetracycline $(250 \mathrm{mg} / \mathrm{l})$. The plates were incubated at $22 \pm 2{ }^{\circ} \mathrm{C}$ for seven days with a $12 \mathrm{hr}$ light/dark regime. Periodically, the plates were screened for the growth of mycelia or discrete colonies on the medium. The growing mycelial portions were transferred to fresh antibiotic-free PDA. The colonies on PDA were cottony with concentric zones, grey in colour with a black underside, and grew with irregular borders.Conidiophores were $80-320 \quad$ x $3.0-4.8 \mu \mathrm{m}$ with mostly three-septate, rarely four-septate, conidia, $18 \times 9 \mu \mathrm{m}$ in size. The walls of the conidia were much thicker than those of other Curvularia spp. with three-septate conidia of the same size. The fungus was identified as Curvularia prasadii R.L. \& B.L. Mathur based on the conidial morphology and colony characteristics given by Mathur \& Mathur (1959) and using standard monographs and taxonomic keys (Barnett \& Hunter 1972; Hawksworth et al., 1995). The identity was further confirmed by the Fungal Identification Service, Mycology and Plant Pathology Group, Agharkar Research Institute, Pune, India (Culture no. OP 91).
To confirm pathogenicity on leaves, disease-free plants were sprayed with a conidial suspension $\left(2 \times 10^{5}\right.$ spores $\left./ \mathrm{ml}\right)$ of the isolated fungus. Control plants were sprayed with sterile water. Inoculated plants and controls were left bagged for 48 hours under greenhouse conditions. After one week, leaf spots similar to those observed on the original diseased plants were observed on the inoculated plants. Control plants did not develop any symptoms. The pathogen was re-isolated from inoculated leaves, fulfilling Koch's postulates. Curvularia prasadii has been reported to cause leaf spot on Jasminum sambac and Costus speciosus in India (Mathur \& Mathur, 1959; Thakur et al., 1980). However, based on the literature, this is the first report of $C$. prasadii causing leaf spot of $A$. aspera.

\section{References}

Barnett HL, Hunter BB, 1972. Illustrated Genera of Imperfect Fungi. Saint Paul, MN, USA: APS Press.

Girach RD, Khan ASA, 1992. Ethananomedicinal uses of Achyranthes apera L. leaves in Orissa (India), International Journal of Pharmacognosy 30, 113-115. [doi:10.3109/13880209209053970]

Hawksworth DL, Kirk PM, Sutton BC, Pegler DN, 1995. Ainsworth and Bisby's Dictionary of the Fungi. 8th edition. Wallingford, Oxford, UK: CAB International.

Mathur RL, Mathur BL, 1959. A new species of Curvularia from the leaves of Jasminum sambac. Current Science 28, 448-449.

Satyavati GV, Raina MK, Sharma M, 1976. Medicinal Plants of India, Volume I. Delhi, India: Indian Council of Medical Research, Cambridge Printing Works, 10-14.

Thakur RN, Pandotra VR, Sastry KSM, 1980. Studies on Curvularia leaf blight of Costus speciosus. Indian Journal of Mycology and Plant Pathology, 117-118.

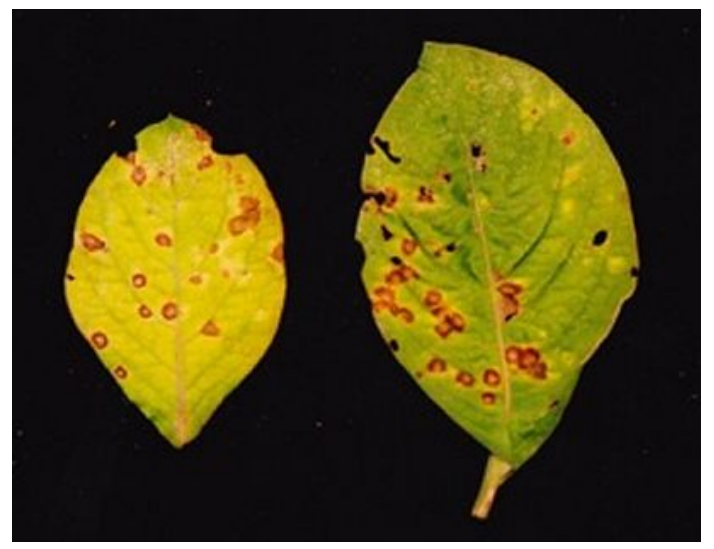

Figure 1

To cite this report: Singh N, Sharma P, Verma OP, 2011. First report of Achyrenthes aspera leaf spot disease caused by Curvularia prasadii in India. New Disease Reports 23, 22. [doi:10.5197/j.2044-0588.2011.023.022]

(c) 2011 The Authors

This report was published on-line at www.ndrs.org.uk where high quality versions of the figures can be found. 